\title{
To Fight, or Not to Fight: Piotr Skarga, the Catholic Ideal of Christian Soldier, and the Reformation of Polish Nobility (around 16oo)
}

\author{
Damien Tricoire \\ Martin Luther-Universität Halle-Wittenberg \\ damien.tricoire@geschichte.uni-halle.de
}

\begin{abstract}
Piotr Skarga was the leading Jesuit in Poland-Lithuania around 160o. In 16o6, he published a catechism for soldiers: Żotnierskie nabożeństwo (The soldier's piety), a book which is commonly said to have been inspired by a catechism by another Jesuit, Antonio Possevino's Il soldato christiano (1569). The aim of this article is to compare the two books and to address the following questions: to what extent and in what way was Possevino's view of soldiers adaptable to Polish-Lithuanian realities? Can we identify a common discourse on soldiers and war in both texts, although they were not written at the same time nor in the same cultural and social context? Or did the strategy of accommodation lead to major differences between the texts, making it difficult to speak of a common Jesuit view on soldiers and war?
\end{abstract}

\section{Keywords}

Society of Jesus - Antonio Possevino - Piotr Skarga - Sigismund Vasa - PolandLithuania - military chaplains - Polish nobility - Ottoman wars - catechisms for soldiers - just war

The Society of Jesus played a critical role in the identification of soldiers as a target of Catholic religious reform. As Lavenia has shown, Jesuits invented both a permanent organization of military chaplains and the literary genre of 
catechisms for soldiers. ${ }^{1}$ The latter was a greater innovation than it seems at first sight. Considering soldiers as a social group needing special missionary efforts was anything but evident in sixteenth-century Europe. Because serving in the army meant being paid for killing both other soldiers and civilians, clerics often viewed this occupation with great suspicion. If a soldier wanted to reach heaven after death, the surest way for him was to change profession, it might seem. By contrast, Jesuit catechisms for soldiers did not suggest that military men should leave the army, but aimed to make "true Christians" out of them.

Against this background, the Jesuits' writing of a catechism for soldiers is a phenomenon that needs to be explained. As we will see, considering this innovation requires us to study the main endeavors of Jesuits in different European countries. This essay will explore the case of a leading Jesuit in Poland-Lithuania around 160o, Piotr Skarga (1536-1612), who among numerous other writings also published in 1606 a catechism for soldiers, entitled The Soldier's Piety, That Is the Teachings, Prayers, and Examples Useful for This Estate. ${ }^{2}$ Skarga was ordained a priest and a canon in Lwów in 1564, and he became a Jesuit five years later. In the following decades, he founded numerous colleges in Poland-Lithuania, and his various occupations included the rectorship of the Jesuit university of Vilnius, 1579-84. In 1588, Sigismund Vasa was elected king of Poland. This meant advancement for Skarga, who had supported him: the Jesuit was named a royal court preacher in 1588 and exercised this function for forty-four years, until his death. ${ }^{3}$

When Skarga published The Soldier's Piety in 1606, he had thus already been for at least eighteen years the most influential Jesuit in Poland-Lithuania. Furthermore, three decades earlier he also had gotten familiar with another well-known Jesuit, Antonio Possevino (1533-1611), who played a critical role in the identification of soldiers as a target of Catholic religious reformation. Indeed, this Mantuan Jesuit had published in $1569 \mathrm{Il}$ soldato christiano, a book which can be considered the very first of all catechisms for soldiers. ${ }^{4}$ Possevino was not only a writer but a diplomat, and it was as a diplomat that he

1 Vincenzo Lavenia, "Tra Cristo e Marte: Disciplina e catechesi del soldato cristiano in età moderna," in Dai cantieri alla storia: "Liber amicorum" per Paolo Prodi, ed. Gian Paolo Brizzi and Giuseppe Olmi (Bologna: CLUEB, 2007), 37-54.

2 Piotr Skarga, Żotnierskie nabożeństwo, to jest nauki, y modlitwy, y przykłady do tego stanu stużące: Pisane od X. Piotra Skargi, Soc. Jesu. a teraz znowu sumptem Nayjaśnieyszego Jana III. króla polskiego (Oliwa: Johann Jakob Textor, 1688).

3 Janusz Tazbir, Piotr Skarga: Szermierz kontrreformacji (Warsaw: Wiedza Powszechna, 1978).

4 Lavenia, "Tra Cristo e Marte," 44-45. 
had the occasion to meet Skarga. The Italian Jesuit was sent as Pope Gregory XIII's legate to Sweden, Poland-Lithuania, and Muscovy in the late 1570s and in the 1580 s. He cooperated intensively with the Polish king Stefan Batory (r.1574-86) to frame a sound policy towards Muscovy. Possevino and Skarga were close and often wrote to each other. They shared a common interest in the conversion of the "schismatic" Orthodoxy. Furthermore, when the Calvinist preacher Andrzej Wolan (1530?-1610) attacked Skarga in 1583, it was Possevino who penned an answer and tried to convince the king to punish the "heretic" for having polemicized against his fellow Jesuit. It was precisely this year that Possevino re-published Il soldato christiano. We know therefore that he was working on this book in that period in which he had intensive contacts with Skarga. ${ }^{5}$

It is thus likely that Skarga's idea to write a catechism for soldiers was inspired by Possevino. However, it should be noted that the Polish Jesuit published his book some twenty-three years after the work by his Italian colleague, and that he did not choose to translate Possevino's book into his mother tongue, but wrote a new one. This surely indicates that the royal preacher thought Il soldato christiano needed to be adapted to another social, cultural, and political context. This article explores the similarities and differences between the two books. It will argue that there was a general coherence in the Jesuits' ideal of Christian soldier while there were yet different intentions underlying these publications.

\section{Militarization of the Christians, Christianization of the Military}

Both Possevino and Skarga open their books with the same assertion: the soldiers' estate is an honorable and Christian one. In Possevino's eyes, God has instituted armies in order to defend truth, justice, and "true peace." The soldiers' role is to maintain the commonwealth, social harmony, and the subordination of the inferiors to their superiors. They are called on to combat rebellions and "scandals." That is why God employs them - in addition to the natural elements and the angels - to avenge offenses again his glory. Fighting under heaven's command, the soldiers could in Possevino's eyes legitimately expect a "big reward" from the Lord. ${ }^{6}$ Even more than his Jesuit colleague,

5 Tazbir, Piotr Skarga, 51-52, 64-66, 70-71, 74-76, 100; Liisi Karttunen, Antonio Possevino: Un diplomate pontifical au XVI ${ }^{e}$ siècle: Thèse présentée à la Faculté des Lettres de l'Université de Helsinki (Lausanne: Pache-Varidel \& Bron, 1908), 95-226.

6 Antonio Possevino, Il soldato christiano, con l'istruttione de' capi dell'essercito catolico (Macerata: Sebastiano Martellini, 1583), 7-9; 18-19. 
Skarga praises the soldiers' calling. For the Polish court preacher, the profession of soldiery is not only necessary to each kingdom and republic, but also "glorious" and "worth honoring." According to him, soldiers feel a special love for their fellow citizens, their fatherland, God's glory, the Christian faith, and the "Church of the Saints," which explains why they risk their life and health to preserve them from any harm. ${ }^{8}$

This assertion of soldiers' dignity should not be understood as a mere captatio benevolentiae strategy. To be sure, it is evident that insulting soldiers would not serve Possevino's and Skarga's aim, which was to write books reaching a wide popularity among the soldiery. However, it seems that the Jesuits were also confronting a real skepticism about soldiers among religious men. Possevino feels the need to claim that soldiers fighting for God's honor can kill without committing a sin. Citing Bernard of Clairvaux (1090-1153), he states that we can not speak of a homicide in this case, but rather of a "malicide." Skarga, for his part, dedicates a whole chapter of The Soldier's Piety to the question of whether soldiers can find salvation as long as they serve in the military. Skarga answers here critics of the soldiers' estate that he unfortunately does not identify. It is thus impossible for us to know if he had anti-Trinitarian or Catholic skeptics in mind. In any case, for the royal court preacher, it was clear that being a soldier did not necessarily entail sinfulness. In his eyes, soldiers did not take up arms to serve their passions; they merely obeyed the orders of the king and the republic. Moreover, they serve God, fighting for his glory, and the good of the fatherland. To be sure, Skarga admitted that the soldiers' profession gave numerous occasions to sin, but he stated that this was true of most professions..$^{10} \mathrm{On}$ the other hand, the Polish Jesuit nevertheless still felt uncomfortable with the idea of killing, even if he does not say so openly. He tells the soldiers not to rejoice after victories. The Polish Jesuit also seems to have thought soldiers were impure after a battle, even when the war was just. He recommends isolating themselves for seven days after fighting, avoiding society, and going to church, following the spirit of a directive given by Moses in the Old Testament. Soldiers should especially refrain from receiving the Holy Sacrament, Skarga suggests. ${ }^{11}$

Despite the royal court preacher's uneasiness about killing, both Possevino and Skarga made clear efforts not only to raise the profile of soldiering, while making it compatible with religious imperatives. Thus, the Polish Jesuit does

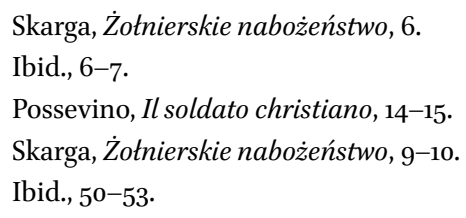

Skarga, Żotnierskie nabożeństwo, 6.

Ibid., 6-7.

Possevino, Il soldato christiano, 14-15.

Skarga, Żotnierskie nabożeństwo, 9-10.

Ibid., $5^{-}-53$. 
not treat with suspicion the soldier's search for mundane glory and "temporal advantages." On the contrary, he approves of it, considering temporal success and glory a reward for virtue. ${ }^{12}$ Possevino and Skarga's view on soldiering surely matched Jesuit endeavors to build harmonious relationships between heaven and earth around 1600 . In the last quarter of the sixteenth and in the first half of the seventeenth century, numerous Jesuits made efforts to give to the faithful a greater feeling of religious security, and to communicate to them more reassuring ideas about human salvation. They reacted against the rigorist Augustinian view of salvation, and, like the Jesuit Luis de Molina (1535-16oo), they defended a semi-Pelagian doctrine. Their basic ideas were that God wants all men to be saved and that the believer can find salvation in every estate through piety and good deeds. Many religious writers, and especially Jesuits, searched for an equilibrium between moral severity and humanism, affirming the value of the laity's state of life. Moreover, they also actively thought about ways to reconcile the imperatives of lay life with religious ones, developing for this reason what came to be called Jesuit casuistry. To a certain extent, they legitimized a plurality of lifestyles and questioned the necessity of renouncing the world. ${ }^{13}$

These efforts to propagate more optimistic ideas about human salvation and to show how religious and mundane life could be compatible did not mean moral and religious laxity, however. Jesuits had generally a highly militant conception not only of their order - they considered themselves to be soldiers "of Christ" - but also of all Christians, as fighters against sin. For this reason, they named the confraternities they founded "sodalities."14 This common conception permitted Possevino and Skarga to blur the boundaries between military

12 Ibid., 16.

13 Alphonse Dupront, "D’un humanisme chrétien en Italie à la fin du Xvi e siècle," in Alphonse Dupront, Genèses des temps modernes: Rome, les Réformes et le Nouveau Monde (Paris: Gallimard-Le Seuil, 2001), 237-49, here 237-38; Robert Bireley, The Refashioning of Catholicism, 1450-1700: A Reassessment of the Counter-Reformation (Washington: Catholic University of America Press, 1999), 175-81; Jennifer Hillman, Female Piety and the Catholic Reformation in France (London: Pickering and Chatto, 2014), 1-46; Anthony D. Wright, The Counter-Reformation: Catholic World and the Non-Christian World (Aldershot: Ashgate, 2005), 163-95; Yves Krumenacker, L'École française de spiritualité: Des mystiques, des fondateurs, des courants, et leurs interprètes (Paris: Cerf, 1999), 88; Françoise Hildesheimer, Relectures de Richelieu (Paris: Publisud, 200o), 41-49; René Taveneaux, Le catholicisme dans la France classique (1610-1715) (Paris: Société d'enseignement supérieur, 1980), 430-32; Harro Höpfl, Jesuit Political Thought: The Society ofJesus and the State (Cambridge: Cambridge University Press, 2004).

14 Louis Châtellier, L'Europe des dévots (Paris: Flammarion, 1987), 73-76. 
and civilian life. Citing St. Paul, they both claimed that everybody was a Christian soldier against the devil. ${ }^{15}$ In this sense, they did not perceive soldiers to be an exception in Christian society.

\section{God, the Poles, and the "Pagans"}

Despite this common endeavor to give the Christian soldier his dignity back in the framework of a "militarization" of Christian life, however, The Soldier's Piety differs markedly from Il soldato christiano. To begin with, one central topic of Skarga's book is missing in Possevino's: Skarga pleads in his catechism for soldiers for a war against "pagans," that is Muslims. He claims that the war against the "enemies of the cross" is the real fulfillment of the soldier's vocation. ${ }^{16} \mathrm{He}$ writes a whole chapter to explain that fighting such a war means gaining an "eternal crown" in heaven, and "chivalrous glory" on earth. ${ }^{17}$

As Poland-Lithuania was a neighbor of the Ottoman Empire-or at least of vassals of the Sublime Porte: the Crimean Tatars, the Moldavian principalities, and Transylvania - and as the war against the Turks was a classical theme of Polish, and more broadly, of European religious discourse, ${ }^{18}$ the presence of this topic in The Soldier's Piety may not seem very surprising. However, it is important to have in mind that before Skarga, few leading Polish political and religious figures pleaded seriously for an offensive war against the Ottoman Empire. Also around 160o, this idea was still highly controversial in PolishLithuanian elites. To be sure, the Polish Christians did not rejoice at the sight of Turkish rule in southeastern Europe. Since 1533, Poland and the Sublime Porte were at peace, but if the Poles avoided provoking their big southern neighbor, it was rather because they feared its military superiority. ${ }^{19}$ For this reason, Sigismund I (1506-48) and Sigismund II Augustus (1548-72) always refused to ally with the emperors and the popes against the Sublime Porte. They argued that, if fighting the Turk was a good deed, it was only possible with a vast coalition of all Christian powers. ${ }^{20}$ In the mid-sixteenth century, the most influential partisan of Counter-Reformation, Cardinal Stanisław Hozjusz (1504-79),

\footnotetext{
15 Possevino, Il soldato christiano, 7, 18; Skarga, Żotnierskie nabożeństwo, 10.

16 Skarga, Żotnierskie nabożeństwo, 15.

17 Ibid., 21-23.

18 Janusz Tazbir, Polska przedmurzem Europy (Warsaw: Twój Styl, 2004), 55-61.

19 Claude Backvis, "Trudne współistnienie pokojowe Polaków i Turków w XVI wieku," in Claude Backvis, Renesans i barok w Polsce: Studia o kulturze (Warsaw: PWN, 1993), 301-44, here 311, 341-42.

20 Backvis, "Trudne współistnienie," 303-8, 315-16.
} 
also took a position against any project of a "Turkish war." According to him, it would be a sin to violate the peace treaty concluded in 1533, and God would punish Poland for that. In his eyes, an offensive war against the Ottoman Empire was conceivable only if the Poles led a "pure life, [...] without licentiousness, $[\ldots]$ with a clear conscience, and would not betray [the Turks]."21

The royal court began to count a significant number of proponents of a war against the Ottomans only in the $1590 \mathrm{os}^{22}$ The imperial armies were then fighting in Hungary and the emperor proposed an alliance to the Polish king. This time, leading Catholic preachers pleaded for war. In a sermon before the diet, Skarga made clear why war against the Turks was in his eyes not only just and useful, but even necessary for the Poles. According to him, the nobility had in peacetime tolerated heresy, blasphemy, licentiousness, and indiscipline. In Poland, divine laws were not respected, and heavenly justice was forgotten. For this reason, Skarga feared God would soon punish the Poles. The "Turkish war" would in his eyes allow them to escape from this dangerous situation, and to show to the Lord that, at least in the field of foreign policy, the Poles fought for His honor. ${ }^{23}$ Skarga, thus, linked the war against the "pagans" with a wider reform program. To him, an aggressive anti-Ottoman policy was attractive because his diagnosis of social and religious (dis)order in his fatherland was a severe one. Like numerous of his fellow Polish Jesuits, he feared God's wrath for his country. ${ }^{24}$

21 Józef Turowski, ed., Deliberacya o spótku i związu Korony Polskiej z pany chrześciańskimi przeciwko Turkowi: Przydane sa poselstwa i responsa stawnego króla Zygmunta Pierwszego (Kraków: Biblioteka Polska, 1858), 7 .

22 Stefan Herman, Wojna i żotnierz w okresie kontrreformacji (do roku 1648): Szkice z dziejów literatury polskiej i obcej (Zielona Góra: Wyższa Szkoła Pedagogiczna, 1983), 6o, 100; Henryk Wisner, Zygmunt III Waza (Wrocław: Ossolineum, 20o6), 76-77; Claude Backvis, "Orientacja stoicka a recepcja Lipsjusza w dawnej Polsce," in Backvis, Renesans i barok w Polsce, 246-81, here 262-73.

23 Herman, Wojna i żotnierz, 6o-64.

24 Stanisław Obirek, Jezuici w Rzeczypospolitej Obojga Narodów w latach 1564-1668 (Kraków: Wydział Filozoficzny Towarzystwa Jezusowego, 1996), 110-13; Mateusz Bembus, Traba gniewu Bożego gromiąc grzeszników: Na przestroge y upamiętanie narodu ludzkiego; Wystawiona w komecie Roku 1618 miesiaca Grudnia, od Wielebnego Księdza Mattheusza Bembusa doktora theol. Soc. Ies. a teraz przez iednego kaptana teraźnieyszym czasom accomodowana (Kraków: W Drukarni Łukasza Kupisza, 1648), 19-21; Hans-Jürgen Bömelburg, "Konfessionspolitische Deutungsmuster und konfessionsfundamentalistische Kriegsmotive in Polen-Litauen um 1600: Durchsetzung und Grenzen in einer multikonfessionellen Gesellschaft," in Konfessioneller Fundamentalismus: Religion als politischer Faktor im europäischen Mächtesystem um 16oo, ed. Heinz Schilling (München: Oldenbourg, 2007), 285-309, here 285 . 
For leading Polish Jesuits and other proponents of Catholic Reformation, war against the Ottomans was a religious necessity, and for this reason an appealing policy. They not only rejected the idea that breaking the oath of alliance with the Sublime Porte would be a sin, but also expected heavenly help in the holy war that would follow. ${ }^{25}$ However, they did not succeed in convincing the Polish-Lithuanian elites. The Polish primate, Stanisław Karnkowski (1520-1603), who had been a close collaborator of the late Hozjusz, admonished the king not to start an offensive war, and he published anew the statements of his mentor and of the kings Sigismund I and Sigismund II Augustus. ${ }^{26}$ Arguing again for a war against the Turks in The Soldier's Piety, Skarga thus appropriated the genre of the catechism for soldiers in order to defend one of his central projects, tightly linked with a negative vision of contemporary Poland and a program of reform.

Skarga's strong plea for an offensive war against "pagans" is not the only difference between The Soldier's Piety and Il soldato christiano, however. In the Polish catechism, one can notice a sharp contrast between a general praise for the ideal of the Christian soldier and strong admonishments to, and a condemnation of, the actual military men of contemporary Poland-Lithuania. By contrast, Possevino's tone is reassuring and optimistic. After having established the dignity of the soldiers' estate and the glory of fighting a war against the "unfaithful," Possevino gives, in the manner of Jesuit casuistry, detailed practical advice to officers and soldiers about the way to prepare themselves for war and to behave properly in it. ${ }^{27} \mathrm{He}$ also promises divine help on the battlefield for the virtuous Christian soldiers fighting in a just war. ${ }^{28}$ Furthermore, he holds out to them the prospect of eternal happiness after death. ${ }^{29}$

Whereas the Italian Jesuit reassures his readers that they are doing right, the Polish court preacher admonishes them to do so. To be sure, Possevino and

25 Piotr Grabowski, Zdanie syna koronnego o pięciu rzeczach rzeczp. polskiej należacych, ed. Kazimierz Józef Turowski (Kraków: Wydawnictwo Biblioteki Polskiej, 1858), 14, 17-21, 24, $31,83-85$.

26 Stanisław Karnkowski, Deliberacja o spotku y zwiazku Korony Polskiey z pany chrześcijańskimi przeciwko Turkowi: Przydane sa poselstwa y responsa stawnego króla Zygmuntha pierwszego (Poznań: n.p., 1595).

27 Possevino, Il soldato christiano, 18-90.

28 Ibid., 82-102.

29 Ibid., 7-9, 18-19. 
Skarga both try to discipline soldiers and to make good Christians out of them. But the Polish court preacher does it with a menacing undertone which is not present in the Italian text. For example, Possevino simply claims that God would not help armies that accept into their ranks "heretical" soldiers, whereas Skarga uses stronger words, stating that God sometimes punishes the whole army because of the sin of only one soldier. ${ }^{30} \mathrm{He}$ writes a whole chapter about the necessity of severe punishments in the army. ${ }^{31}$ Furthermore, he places at the end of his book an unflattering portrait of contemporary Polish military men. In the court preacher's eyes, almost all of them preferred to be clothed in silk rather than to cultivate military virtue. Furthermore, they plundered their own country, and shed Polish blood instead of defending the common good. ${ }^{32}$

In the end, Skarga is less interested than Possevino in clarifying matters of detail concerning the behavior of soldiers. To be sure, he explains how soldiers should prepare themselves spiritually before the battle, and how they should behave afterwards. ${ }^{33} \mathrm{He}$ also deals with the question of what soldiers should do at home, a topic Possevino does not touch on. ${ }^{34}$ But Skarga's central endeavor is to admonish the soldiers to participate only in just wars. Directly after having assessed the dignity of the soldiers' calling, the Polish Jesuit asks the question: in which kind of war should the Christian soldier join the army? Contrary to other Jesuit catechisms for soldiers of his time, ${ }^{35}$ the court preacher's book claims that the soldier should examine the character of the war before enrolling, and enlist himself only if the war is "clearly just." Firstly, the war should have been declared by the highest authority of the commonwealth. According to the Polish Jesuit, subjects and nobles have never the right to seek justice by violent means, but should rather go to court. Civil war is always unjust and fighting such a war leads with certainty to eternal damnation. Secondly, the Christian soldier should not take part in offensive wars, undertaken by princes only wanting to enlarge their territory, and not for the sake of religion. To be sure, Skarga states that a soldier following the orders of his prince does no wrong. In his eyes, obedience can be considered a sufficient excuse. But at the same time, he claims that this excuse is not valid when the war is clearly and evidently unjust. The soldier should then rather obey God than men, he says. ${ }^{36}$

\footnotetext{
$30 \quad$ Ibid., 34-37; Skarga, Żotnierskie nabożeństwo, 40-42.

31 Skarga, Żotnierskie nabożeństwo, 36-39.

32 Ibid., 59-6o.

33 Ibid., 44-55.

34 Ibid., $55^{-59}$.

35 Lavenia, "Tra Cristo e Marte," 48.

$36 \quad$ Skarga, Żotnierskie nabożeństwo, 17-20.
} 
In the following chapters of The Soldier's Piety, Skarga dwells further on the topic of the just war. He maintains anew that war should only serve public peace ${ }^{37} \mathrm{He}$ repeats that it is not permitted to use the sword against neighbors, innocents, and poor people, but only against the enemies of the fatherland. ${ }^{38}$ In the last section of his book, he formulates two vows for the military men: with the first one, the soldiers had to swear that they would only serve their king and their fatherland; with the second one, they would swear that they would not take part in any unjust or dubious war. ${ }^{39}$

How can we explain these differences in tone and content between Il soldato christiano and The Soldier's Piety? A close contextualization and reading of both catechisms makes clear that they were not written for the same audience and for the same purpose. As it is well known, Possevino had been commissioned to compose Il soldato christiano by Pope Pius V and Francisco de Borja, the superior general of the Society of Jesus $\left(1565^{-72}\right)$, who wanted to have a book they could distribute to the pontifical army waiting at Turin for the order to march into France and fight the Huguenots. ${ }^{40}$ Hence Il soldato christiano was designed to discipline the soldiers and incite them to virtue, and also to give them courage on the battlefield. For this reason, Possevino assured the soldiers that they could expect heavenly help and reward. Furthermore, his aim was to transform mercenaries into agents of a holy war, and this incited him to give precise advice to officers about the way they should behave, recruit their soldiers, and discipline them. ${ }^{41}$

By contrast, the audience of The Soldier's Piety was not mercenaries, but Polish-Lithuanian noblemen. In seventeenth-century Poland-Lithuania, the feudal system still played a crucial military role, and mercenary companies a lesser one than in Western Europe. It is remarkable that in The Soldier's Piety, Skarga uses interchangeably the words "soldier" (zotnierz), that is a term designating someone who gets money to fight, and "knight," meaning in his own idiom not precisely a noble title, but the totality of the lesser noblemen, all of whom he expect to fight on the battlefields for the king and the commonwealth. This notional confusion was not innocent, but rather an instrument to remind noblemen that fighting should be the prime occupation of their calling. In other words, Skarga endeavored not only a Christianization of the soldiers and a militarization of the faithful, but also a militarization of

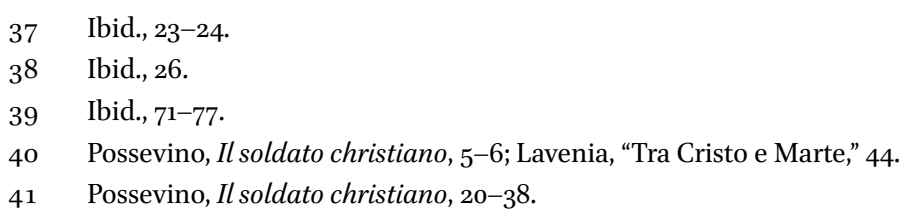


nobility - this time in the narrow sense of the word. This explains his criticisms of soldiers dressed in silk, and who did not train for war-a type of soldier that the preacher calls "an old woman" (stara baba) to underline his effeminacy and lack of physical strength. ${ }^{42}$

Furthermore, also in apostrophizing noblemen, Skarga has recourse to a patriotic discourse absent from Possevino's book. "Fatherland" and "commonwealth" are common slogans in The Soldier's Piety. ${ }^{43}$ The court preacher also refers several times to the fame of their ancestors, the old Poles and Slavs, named according to him after the word "glory" (stawa) $\cdot{ }^{44}$ If one keeps in mind that Skarga wrote his book not for professional soldiers, but for noblemen fighting only occasionally on the battlefield, it also becomes clearer why he insists so much on the legitimacy of punishments given by the generals - not always accepted by the nobles - and on the illegality and immorality of private justice, that is of feuds, which were still common in Poland-Lithuania around $1600 .{ }^{45}$

The condemnation of illegitimate violence had also to do with a more serious problem, however. Skarga published his book in 1606, on the eve of a noble rebellion known in historiography as the rokosz of Sandomierz, or of Zebrzydowski. A rokosz was an uprising considered by its defenders to be legal on the basis of a right of resistance to tyranny. When the commonwealth was menaced and could not be defended in the usual institutional manner, the partisans of this doctrine claimed, the noblemen had a right to disobey king and senators and to form an assembly, called rokosz, to judge the authorities. Of course, this theory, first formulated in 1532, was far from being consensual in Poland-Lithuania. ${ }^{46}$ Neither was the legitimacy of the assembly convened by the rebellious noblemen in 1606 .

Despite the fact that the rokosz of Sandomierz is usually considered in historiography to be a typical expression of Polish noblemen's ideology, ${ }^{47}$ the

\section{Skarga, Żotnierskie nabożeństwo, 60.}

43 For example, Skarga, Żotnierskie nabożeństwo, 10, 14, 15, 23, 26, 28-29, 46, 6o, 62, 71.

44 Ibid., $15^{-16,60 .}$

45 Ibid., 17-18.

46 Aleksander Rembowski, Konfederacya i rokosz $w$ dawnem prawie państwowem polskim: Studium porównawcze (Warsaw: Gebethner i Wolff, 1893), 283-85.

47 Janusz Tazbir, “Jezuici między Rzecząpospolitą a Rzymem," in Szkice z dziejów papiestwa, vol. 1, ed. Irena Koberdowa and Janusz Tazbir (Warszawa: Książka i Wiedza, 1989), 74-132, here 88; Inger Auerbach, "The Bohemian Opposition, Poland-Lithuania and the Outbreak of the Thirty Years' War," in Crown, Church and Estates: Central European Politics in the Sixteenth and Seventeenth Centuries, ed. Robert J.W. Evans and T.V. Thomas (New York: St. Martin's Press, 1991), 196-225, here 201; Gottfried Schramm, "Armed Conflict in 
insurgents' causes of discontent were in reality diverse. The rokoszanie-as the partisans of the rokosz were called-made a common front against the king's projects to introduce new taxes destined to finance a permanent army. They also resented Sigismund III's alliance with the Habsburgs and his strong commitment to Counter-Reformation. Not only did Protestants feel threatened by the king's confessional policy; Catholic elites did also, influenced by the humanist tradition, which had dominated the royal court under the last king Stefan Batory, thought Counter-Reformation to be dangerous. In this context, Jesuits in general, and Skarga in particular, became favorite targets of the rokoszanie. ${ }^{48}$ For example, the author of a pamphlet defending the rokosz distinguishes "new Catholics" from "old" ones, the virtuous Polish ancestors. According to him, the latter, contrary to the former, distinguished clearly between spiritual and temporal affairs, and they did not slavishly obey clerics in political matters. The message was clear: the king was accused of being submissive to the Society of Jesus. ${ }^{49}$ Sigismund's ostentatious piety, so typical of the Jesuit style, was also criticized, and mocked. ${ }^{50}$

Confronted with the prospect of civil war, and of a military campaign against his king, his order, and lastly himself, Skarga's main intention in writing The Soldier's Piety may have been to admonish the nobles not to take part in the rebellion. Against this background, it becomes clear why the royal court preacher so strongly warned the "knights" not to participate in unjust, or dubious, wars, and threatened them with divine temporal and eternal punishment.

East-Central Europe: Protestant Noble Opposition and Catholic Royalist Factions, 160420," in Crown, Church and Estates, 176-95, here 187-88.

48 Jarema Maciszewski, Wojna domowa w Polsce (1606-16og): Studium z dziejów walki przeciw kontrreformacji, 2 vols. (Wrocław: Zakład Narodowy im. Ossolińskich, 1960); Wisner, Zygmunt III, 91-98; Claudio Madonia, La Compagnia di Gesù e la riconquista cattolica dell'Europa orientale (Genoa: Name, 2002), 286-87, 298; Michael G. Müller, Kleine Geschichte Polens (Frankfurt/Main: Suhrkamp, 2000), 157; Winfried Eberhard, "Voraussetzungen und strukturelle Grundlagen der Konfessionalisierung in Ostmitteleuropa," in Konfessionalisierung in Ostmitteleuropa: Wirkungen des religiösen Wandels im 16. und 17. Jahrhundert in Staat, Gesellschaft, Kultur, ed. Joachim Bahlcke and Arno Strohmeyer (Stuttgart: Steiner, 1999), 89-103, here 97; Auerbach, "The Bohemian Opposition," 203.

49 "Jezuitom i inszem duchownem respons, którzy dla artykułów niektórych, sobie nie ku myśli uchwalonych, rokosz buntem heretyckim zowią [...]," in Pisma polityczne z czasów rokoszu Zebrzydowskiego 1606-16o8, ed.Jan Czubek (Kraków: Nak. Akademii Umiejętności, 1916-18), 1:81-93, here 82-83.

$50 \quad$ "Pacierz do króla Jegomości," in Czubek, ed., Pisma polityczne, 1:33-34; "Rozmowa o rokoszu," in Czubek, ed., Pisma polityczne, 2:102-36, here 104-6. 
Whereas Possevino's goal was to prepare the soldiers to fight, Skarga's catechism for soldiers was on the contrary probably principally written to prevent a war, or at least to dissuade a part of the nobility from fighting on the wrong side. In his book, the last of the prayers he wished the "knights" to recite is not about victory, but about peace..$^{51}$

51 Skarga, Żotnierskie nabożeństwo, 83-86. 